\title{
Are breast cancers driven by fusion genes?
}

\author{
Paul A W Edwards* and Karen D Howarth
}

\begin{abstract}
For many years, it was assumed that gene fusions were a type of mutation confined largely to leukemias and sarcomas. However, fusion genes are now known to be important in several epithelial cancers and a number have been described in breast cancers. In the December 2011 issue of Nature Medicine, Robinson and colleagues reported many more gene fusions including the first recurrent fusion, SEC16A-NOTCH1 - in breast cancers. Several genes, including members of the MAST (microtubule-associated serine threonine) kinase and Notch gene families, are fused more than once. This finding supports an emerging story that most breast cancers express a number of fusion genes.
\end{abstract}

A recent paper by Robinson and colleagues [1] is the latest in a developing story that fusion genes are not only present but abundant in epithelial cancers such as carcinoma of the breast, ovary, and prostate [2]. This story started in 2005 with the identification of the recurrent gene fusion TMPRSS2-ERG in around $50 \%$ of prostate cancers [3]. Robinson and colleagues reported a number of fusion gene transcripts that they found in a panel of breast cancer cell lines and tumors, adding substantially to the tally of known fusion genes in breast cancers.

Fusion genes are formed when a structural rearrangement of the genome, such as a deletion, inversion, tandem duplication, or translocation, results in the joining of two unrelated genes. The best-known example is $B C R-A B L$ in chronic myeloid leukemia. Gene fusion is probably the most powerful way of mutating a gene as it can have multiple effects on the fused proteins. It also creates genes and proteins that are tumor-unique and that therefore serve as drug targets and markers for diagnosis and monitoring [4]. In $B C R-A B L, A B L$ encodes a tyrosine kinase. Translocation removes a domain that

*Correspondence: pawe1@cam.ac.uk

Hutchison/MRC Research Centre and Department of Pathology, University of Cambridge, Hills Road, Cambridge, CB2 0XZ, UK normally inhibits the kinase by intramolecular binding [5] and replaces it with a fragment of Bcr that spontaneously oligomerizes and hence activates the tyrosine kinase [6]. $B C R-A B L$ is used in diagnosis and monitoring and is a target for the drug Glivec/Gleevec (imatinib; Novartis, Basel, Switzerland) [7].

Robinson and colleagues [1] found fusion genes in breast cancer by sequencing cDNA from 41 breast cancer cell lines and 38 breast tumors. The main focus of the paper is that the MAST (microtubule-associated serine threonine) kinase and Notch gene families are repeatedly fused - in around $4 \%$ and $6 \%$ of cases, respectively - and one fusion was present in two cases, qualifying as the first example of a recurrent fusion in breast cancer. MAST fusions increased proliferation in benign breast epithelial cells, whereas cell lines with Notch fusions were sensitive to inhibitors of Notch signaling. Strikingly, all cases with Notch fusions were estrogen receptornegative and seven out of eight were triple-negative.

The authors also reported many other expressed fusion genes, supporting the emerging view that breast cancers harbor multiple fusions. Furthermore, 14 of the genes that are listed as fused are fused more than once in these tumors, suggesting that the fusions are not merely random events (although these genes are fused to a different partner gene in each instance, except in the case of the SEC16A-NOTCH1 fusion). The authors detected, on average, 5.5 fusions per cell line and 4.2 fusions per tumor, although any individual breast tumor expressed between 0 and 20 gene fusions. Fusion gene data are now available for approximately 42 breast cancer cell lines [1,8-12], and the highest total so far is 24 fusion genes in MCF7 cells $[1,8,11]$.

However, these reports are all incomplete. Current high-throughput sequencing does not find all rearrangements, it only randomly samples them; and the software generally reports only the most confident hits. Robinson and colleagues have found about one third to one half of the fusions expressed in lines for which there are data from other approaches. The authors listed five of 11 known MCF7 fusions [11] and 11 of 25 expressed fusions found by Stephens and colleagues [9] in cell lines and tumors, and this is consistent with our unpublished work. The fusion searches that have been based on analysis of genomic rearrangements $[9,13]$, rather than 
on sequencing of cDNA, have also been incomplete, as judged by comparing the junctions reported with Array Comparative Genomic Hybridization data.

Another lesson from emerging fusion gene data is that most fusion genes are not formed by chromosome translocations but by intrachromosomal rearrangements such as deletions, inversions, and tandem duplications (reviewed in [2]). In the paper by Robinson and colleagues [1], $77 \%$ of the rearrangements (296 out of 383) are intrachromosomal.

Why did the epithelial cancer field overlook fusion genes as an important kind of mutation? Fusions had been considered to be a feature of leukemias, not epithelial cancers such as breast cancer, but this merely reflected our ignorance [14]. The cytogenetics of carcinomas shows large numbers of rearrangements, many of them unbalanced. It was argued that this genomic mayhem was mostly noise or irrelevant late-progression events, that most selected rearrangements reflected loss of tumor suppressors, and that this was supported by the apparent lack of highly recurrent rearrangements analogous to the iconic $B C R-A B L$ gene in chronic myeloid leukemia. None of these was a strong argument [2]; we had underestimated the sheer number of gene changes in tumors; tumor suppressor gene loss may account for some rearrangements but not all of them; and the $B C R$ $A B L$ paradigm is misleading, as very few fusion genes are present in a high proportion of cases of a disease, the vast majority of fusion genes - even in leukemias - being rather rare [15].

Fusions may be abundant in breast cancers, but are they meaningful? Some may be noise. Some most likely inactivate genes [8]. However, many seem to involve cancer-relevant genes such as chromatin modifiers and signaling proteins, and now Robinson and colleagues have described fusions of the MAST kinase and Notch gene families and provide evidence that they are functional.

By extrapolation from the emerging data, many breast cancers may have 10 to 20 fusion genes in addition to their point-mutated, deleted, and amplified genes and genes silenced by methylation. Given the power of fusion as a type of mutation, fusion genes are likely to make a substantial contribution to the development of breast cancer.

\section{Abbreviation}

MAST, microtubule-associated serine threonine.

\section{Competing interests}

The authors declare that they have no competing interests.

\section{Acknowledgments}

The authors' work is supported by Cancer Research UK and Breast Cancer Campaign.
Published: 16 March 2012

\section{References}

1. Robinson DR, Kalyana-Sundaram S, Wu YM, Shankar S, Cao X, Ateeq B, Asangani IA, lyer M, Maher CA, Grasso CS, Lonigro RJ, Quist M, Siddiqui J, Mehra R, Jing X, Giordano TJ, Sabel MS, Kleer CG, Palanisamy N, Natrajan R, Lambros MB, Reis-Filho JS, Kumar-Sinha C, Chinnaiyan AM: Functionally recurrent rearrangements of the MAST kinase and Notch gene families in breast cancer. Nat Med 2011, 17:1646-1651.

2. Edwards PAW: Fusion genes and chromosome translocations in the common epithelial cancers. J Pathol 2010, 220:244-254.

3. Tomlins SA, Rhodes DR, Perner S, Dhanasekaran SM, Mehra R, Sun XW, Varambally S, Cao X, Tchinda J, Kuefer R, Lee C, Montie JE, Shah RB, Pienta KJ, Rubin MA, Chinnaiyan AM: Recurrent fusion of TMPRSS2 and ETS transcription factor genes in prostate cancer. Science 2005, 310:644-648.

4. Mitelman F, Johansson B, Mertens F: The impact of translocations and gene fusions on cancer causation. Nat Rev Cancer 2007, 7:233-245.

5. Hantschel O, Superti-Furga G: Regulation of the c-Abl and Bcr-Abl tyrosine kinases. Nat Rev Mol Cell Biol 2004, 5:33-44.

6. Beissert T, Puccetti E, Bianchini A, Güller S, Boehrer S, Hoelzer D, Ottmann OG, Nervi C, Ruthardt M: Targeting of the N-terminal coiled coil oligomerization interface of $B C R$ interferes with the transformation potential of $B C R-A B L$ and increases sensitivity to STI571. Blood 2003, 102:2985-2993.

7. Druker BJ, Lydon NB: Lessons learned from the development of an abl tyrosine kinase inhibitor for chronic myelogenous leukemia. J Clin Invest 2000, 105:3-7.

8. Hampton OA, Den Hollander P, Miller CA, Delgado DA, Li J, Coarfa C, Harris RA, Richards S, Scherer SE, Muzny DM, Gibbs RA, Lee AV, Milosavljevic A: A sequence-level map of chromosomal breakpoints in the MCF-7 breast cancer cell line yields insights into the evolution of a cancer genome. Genome Res 2009, 19:167-177.

9. Stephens PJ, McBride DJ, Lin ML, Varela I, Pleasance ED, Simpson JT, Stebbings LA, Leroy C, Edkins S, Mudie LJ, Greenman CD, Jia M, Latimer C, Teague JW, Lau KW, Burton J, Quail MA, Swerdlow H, Churcher C, Natrajan R, Sieuwerts AM, Martens JW, Silver DP, Langerød A, Russnes HE, Foekens JA, Reis-Filho JS, van't Veer L, Richardson AL, Børresen-Dale AL, et al.: Complex landscapes of somatic rearrangement in human breast cancer genomes. Nature 2009, 462:1005-1010.

10. Zhao Q, Caballero OL, Levy S, Stevenson BJ, Iseli C, de Souza SJ, Galante PA, Busam D, Leversha MA, Chadalavada K, Rogers YH, Venter JC, Simpson AJ, Strausberg RL: Transcriptome-guided characterization of genomic rearrangements in a breast cancer cell line. Proc Natl Acad Sci U S A 2009, 106:1886-1891.

11. Hampton OA, Miller CA, Koriabine M, Li J, Den Hollander P, Carbone L, Nefedov M, Ten Hallers BF, Lee AV, De Jong PJ, Milosavljevic A: Long-range massively parallel mate pair sequencing detects distinct mutations and similar patterns of structural mutability in two breast cancer cell lines. Cancer Genet 2011, 204:447-457.

12. Inaki K, Hillmer AM, Ukil L, Yao F, Woo XY, Vardy LA, Zawack KF, Lee CW, Ariyaratne PN, Chan YS, Desai KV, Bergh J, Hall P, Putti TC, Ong WL, Shahab A, Cacheux-Rataboul V, Karuturi RK, Sung WK, Ruan X, Bourque G, Ruan Y, Liu ET: Transcriptional consequences of genomic structural aberrations in breast cancer. Genome Res 2011, 21:676-687.

13. Howarth KD, Blood KA, Ng BL, Beavis JC, Chua Y, Cooke SL, Raby S, Ichimura K, Collins VP, Carter NP, Edwards PA: Array painting reveals a high frequency of balanced translocations in breast cancer cell lines that break in cancerrelevant genes. Oncogene 2008, 27:3345-3359.

14. Mitelman F, Johansson B, Mertens F: Fusion genes and rearranged genes as a linear function of chromosome aberrations in cancer. Nat Genet 2004, 36:331-334.

15. Mitelman F, Mertens F, Johansson B: Prevalence estimates of recurrent balanced cytogenetic aberrations and gene fusions in unselected patients with neoplastic disorders. Genes Chromosomes Cancer 2005, 43:350-366.

doi: $10.1186 / \mathrm{bcr} 3122$

Cite this article as: Edwards PAW, Howarth KD: Are breast cancers driven by fusion genes? Breast Cancer Research 2012, 14:303. 